УДК $78.03(07)$

DOI:

Тетяна Крижановська, кандидат педагогічних наук, доиент кафедри історії, теорії музики та методики музичного виховання Інституту мистецтвв Рівненського державного гуманітарного університету

\title{
МЕТОДИЧНІ АСПЕКТИ РЕАЛІЗАЦЇ̈ ІНТЕГРАТИВНОГО ПІДХОДУ У ПРОЦЕСІ ВИКЛАДАННЯ КУРСУ “ІСТОРІЯ МУЗИКИ" ДЛЯ МАЙБУТНІХ УЧИТЕЛІВ МИСТЕЦТВА
}

У статті розглядаються методичні позичї, щуо сприяють ефективності використання інтегративного підходу в умовах професійної підготовки вчителів мистецтвв. Пропонується структура особистісного художнього розвитку як важливого показника фахової компетентності вчителя мистецтва, що розглядається як об 'єкт інтегрованого впливу в курсі “Історія музики”. Узагальнюються форми та методи реалізачії інтегративного підходу у визначених структурних складових (інтелектуальній, емоційно-ціннісній та діяльнісній). Наводяться приклади з практичного досвіду автора.

Ключові слова: освітня інтеграція; художній розвиток особистості; икільний інтегрований курс "Мистецтво”"; професійна підготовка вчителя мистецтвва; дисципліна "Історія музики”.

Jim. 9.

Tetyana Kryzhanovska, Ph. D. (Pedagogy), Associate Professor of the History, Theory of Music and Methodics of Musical Education Department of the Institute of Arts, Rivne State Humanitarian University

\section{METHODICALASPECTS OF REALISATION OF THE INTEGRATIVE APPROACH DURING THE PROCESS OF STUDYING THE COURSE "MUSIC HISTORY" FOR FUTURE ART TEACHERS}

This article focuses on the methodical positions of use of the integrative approach in the professional training of art teachers. The relevance of this approach (in terms of socio-historical, national and educational factors) is substantiated in various aspects. The author emphasizes the need to train the teacher of the New Ukrainian School as a specialist, who is capable of independent innovative artistic and educational activities of integrative content, in particular in the context of teaching the "Art" discipline. The process of teaching the course "History of Music" in a higher education institution was chosen as a medium of using an integrative approach as a system-forming mechanism for the professional and pedagogical formation of a future specialist. Considering the previous musicological experience of the higher pedagogical education students, an integrative approach is noted as one that allows the teacher to differentiate the content of the discipline, to individualize and professionally direct the educational process, providing it with the necessary continuity in the way from basic knowledge, skills to systems of knowledge and system of skills. The meaning of "Integration" has been explored in the philosophical and pedagogical aspects. The specificity of kinds of the integrative mechanism was analyzed in terms of substantive and processual criterias. The artistic development of the individual was highlighted as an important indicator of the professional competence of the art teacher. Its structure under consideration was suggested as a Differentiated object of Integrated Impact in Music History Course. Objects of artistic integration in the educational process identified the intellectual, emotional-value and activity components of the personal artistic development of the potential teacher. The forms and methods of implementation of the integrative approach are summarized according to suggested structure. The article describes examples of the practical experience of the author, illustrating the peculiarities of using different kinds of integration as a mechanism of differentiated and holistic influence on the artistic development of a future teacher of the integrated course "Art".

Keywords: an educational integration; artistic development of personality; school integrated "Art" course; professional training of art teacher; "History of Music" discipline.

П остановка проблеми. Люди XXI ст. є учасниками процесу всесвітньої інтеграції та уніфікації, який отримав назву “глобалізація". Остання охоплює різні складові суспільної свідомості, що потребує вироблення світогляду, орієнтованого на “"загально цивілізаційний процес планетарного єднання різних сфер людської діяльності” [3, 29]. I хоч традиційно глобалізацію пов'язують передовсім з економікою, політикою, вона охопила і таку важливу частину суспільного буття як культура, зокрема освіта, мистецтво. Так, сучасна українська педагогічна освіта, адаптуючись до зазначених змін у житті суспільства, переживає всебічне оновлення, 


\section{МЕТОДИЧНІ АСПЕКТИ РЕАЛЮЗЦӤ̈ ІНТЕГРАТИВНОГОПДХОДУ У ПРОЦЕСІ ВИКЛАДАННЯ КУРСУ “ІСТОРІЯ МУЗИКИ” ДЛЯ МАЙБУТНІХ УЧИТЕЛІВ МИСТЕЦТВА}

орієнтоване на підготовку високоякісних фахівців для Нової української школи. Учитель, який працює в умовах реформованої шкільної освіти, повинен орієнтуватись на концептуальний вектор: НУШ - “це школа, ... яка даватиме учням не тільки знання, ... а й вміння застосовувати їх у житті” [1], що передбачає інтегрування отриманого досвіду з різних предметних галузей у самостійній діяльності школяра. Не випадково спостерігаємо активне впровадження комплексного навчання у шкільне освітнє середовище. Наприклад, мета та завдання освітньої галузі “Мистецтво” реалізовуються через інтегрований курс “Мистецтво”, що прийшов на зміну традиційному ізольованому викладанню мистецьких дисциплін у 1-8-х класах. Водночас він є близьким за змістом курсу “Художня культура. 9-11 класи”, нещодавно вилученому із шкільної освіти.

Проблема інтеграції у мистецькій освіті сьогодні активно досліджується науковою спільнотою. Зокрема уточнюється зміст даного поняття (І. Дичківська, О. Олексюк, Н. Свєтловська), критерії класифікації (С. Карпенчук, Л. Масол, Г. Шевченко); методичні аспекти ефективної реалізації як дидактичного методу (О. Гайдамака, Л. Масол, О. Просіна) тощо. Водночас методичним особливостям впровадження інтеграції як принципу художньо-педагогічної освіти та важливої умови фахової підготовки майбутніх вчителів мистецтва приділено значно менше наукової уваги, що зумовлює інтерес автора статті до зазначеної проблеми. Оскільки у шкільній практиці інтегрований курс "Мистецтво" часто викладають вчителі музичного мистецтва, то важливо, щоб зміст передбачених освітніми програмами дисциплін мав професійне спрямування і сприяв подоланню суперечності між традиційним предметним викладанням та інтегрованим змістом майбутньої фахової діяльності здобувачів вищої освіти. Це вимагає впровадження інтегративного підходу, наприклад, у процесі викладання дисципліни “Історія музики”.

Мета запропонованої статті - визначення методичних позицій, що забезпечують результативність фахової підготовки вчителя мистецтва в курсі "Історія музики”.

Системність професійної підготовки вчителя значною мірою забезпечується таким системотвірним механізмом, як інтеграція (від лат. integrum - ціле, integratio - відновлення), тобто об'єднання в ціле будь-яких окремих елементів (частин); поєднання, координація дій різних частин цілісної системи [2, 508]. Науковець Н. Свєтловська вважає, що інтеграція - це створення цілісного нового на основі виявлених однотипних елементів та частин в декількох раніше різних одиницях (навчальних предметах, темах, видах діяльності і т.д.), подальше їх пристосування та об'єднання в неіснуючий досі моноліт [8, 57-60]. Л. Масол підкреслює, що цей механізм конструювання цілісності - не штучне сумування елементів, а відродження природних, об'єктивно існуючих зв'язків і перехід у нову якість [7, 8].

На думку дослідниці С. Карпенчук, інтеграція у змісті освіти - це об'єднання в одному навчальному предметі узагальнених знань певної наукової галузі [4, 552]. О. Мариновська в педагогічному контексті розуміє інтеграцію як засіб педагогічної діяльності, що передбачає пошук спільних платформ для зближення предметних знань; як мету навчання, що спрямовується на формування цілісних знань, творення власного “образу світу” у свідомості школяра [6, 3-5].

Щодо видової специфіки мистецької освітньої інтеграції, то у сучасній педагогіці сформувалася низка позицій. Наприклад, за критерієм змісту інформаційної інтеграції пропонується духовносвітоглядна, естетико-мистецтвознавча, комплексна [7]; предметна, міжпредметна, загально предметна інтеграція [5]. За змістом діяльнісної інтеграції можна виділити, комунікативно-творчу, виконавсько-інтерпретаційну та ін. За процесуальним параметром - синтетичний, послідовний, відтворюючий [9]; передуючий, супутній їі види [4] тощо.

Результатом, зокрема, міжпредметної інтеграції став вищезгадуваний шкільний курс “Мистецтво”, зорієнтований на художній розвиток особистості, тобто на процес опанування нею мистецтва, перетворення суспільної художньої культури в індивідуальну особистісну. Художня розвиненість вчителя даної дисципліни є важливим показником його фахової компетентності. В дослідженнях 3 художньої педагогіки термін “художній розвиток" часто використовується разом з поняттями “поліхудожній”, “полімистецький розвиток” (О. Бузова, О. Рудницька та ін.), які, по суті, $є$ синонімічними, відтворюючи інтегративність змісту розвивальних методик. Задля результативності педагогічного впливу вважаємо доцільним виділення об’єктів впливу мистецької інтеграції відповідно до структури даного процесу. Так, поєднання різнопредметної дидактичної інформації формує систему мистецьких знань. Їх використання у розумовій, вербальній, практичній діяльності розвиває інтелектуальну складову художнього розвитку. Об’єднаний мистецький вплив підсилює 


\section{МЕТОДИЧНІ АСПЕКТИ РЕАЛІЗАЦІЇ ІНТЕГРАТИВНОГО ПДХОДУ У ПРОЦЕСІ ВИКЛАДАННЯ КУРСУ “ІСТОРІЯ МУЗИКИ” ДЛЯ МАЙБУТНІХУЧИТЕЛІВ МИСТЕЦТВА}

емоційне реагування особистості, зокрема на рівні вищих (інтелектуальних, моральних, естетичних) почуттів як важливої передумови формування системи художніх цінностей. Стимулювання художньої активності, що реалізується у різномистецькій діяльності, забезпечує вплив на діяльнісний компонент художнього розвитку особистості. Таким чином, об’єктами мистецької інтеграції у освітньому процесі $є$ інтелектуальна, емоційно-ціннісна та діяльнісна складові. До їх цілісного розвитку готуємо майбутніх вчителів мистецтва, інтегруючи у освітній процес елементи шкільної методики мистецької освіти.

У полі нашого зору - педагогічно доцільне об'єднання в межах навчальних тем курсу “Історія музики” різнопредметних інформації, методів її викладу, видів діяльності, що здійснюється з метою підвищення ефективності освітнього процесу, поглиблення його професійної спрямованості. При цьому ми зважаємо на чинник, який може даний процес суттєво загальмувати. Мова йде про попередній досвід здобувача вищої освіти у сфері історичного музикознавства. Адже студентський контингент за спеціальністю “вчитель музичного мистецтва" традиційно є доволі різноманітним. Переважно це випускники дитячих музичних шкіл, музичних та педагогічних коледжів, хоч $є$ також здобувачі вищої освіти без попередньої музичної освіти. Нагадаємо: освітні програми дитячих музичних шкіл включають предмет "Музична література”, змістом якого є елементарні відомості з історії музики. Ця загальнопізнавальна дисципліна передбачає початкове ознайомлення учнів із зразками музичної творчості, формування елементів базових знань, елементарних навичок слухового спостереження, розвиток інтересу до музичного мистецтва.

Освітні програми музичних коледжів включають аналогічну за назвою дисципліну, яка забезпечує більш глибоке пізнання музичної творчості, формує основи стильового орієнтування студентів в умовах початкової систематизації музично-історичних знань. Продовження процесу розвитку музичного світогляду як системи уявлень, поглядів, переконань, ціннісних орієнтацій у світі музичного мистецтва, а тому - важливої складової компетентності вчителя відбувається в курсі 3ВО "Історія музики".

Саме інтегративний підхід, на нашу думку, дозволяє викладачу диференціювати зміст дисципліни, індивідуалізувати та професійно спрямовувати освітній процес, зорієнтовуючи його як на вище названі структурні компоненти особистісного художнього розвитку, так і на цілісну фахову компетентність вчителя інтегрованого курсу “Мистецтво”. На прикладі теми курсу "Історія музики" "Музичне мистецтво східних слов'ян” проілюструємо вище наведені положення.

Українська народна, зокрема, календарнообрядова творчість - вагома дидактична складова шкільної мистецької освіти. Залучення музичного фольклору до навчального процесу має ряд методичних особливостей, зокрема: дотримання вікової специфіки у здійсненні інформаційного забезпечення навчального процесу, музично-аналітичної, виконавської діяльності вчителя та учнів; розроблення системи завдань, спрямованих на художній (інтелектуальний, емоційно-ціннісний та діяльнісний) розвиток учнів; забезпечення об'єднаного мистецького впливу. Саме тому ми приділили особливу увагу зазначеній темі, інтегрувавши у зміст практичного заняття та індивідуальної роботи з історії музики елементи методики викладання шкільного курсу "Мистецтво".

Метод “мистецькі паралелі” реалізувався у асоціативних рядах, створених здобувачами вищої освіти: літературно-поетичних ("Перебендя" T. Шевченка, “Веснянки” I. Франка, “Два віночки” Я. Головацького, легенди давньої України тощо); музичних (“Дихання океану” Каті Chilli, “Весна" О. Скрипки, різдвяних композиції “Пікардійської терції” та ін.); живописних (“Колядки на Україні” К. Трутовського, “На ріллі. Весна" О. Венеціанова, “Святочне ворожіння" М. Пимоненка), графічних (роботи рівненського письменника-художника В. Войтовича на теми слов'янської міфологіi).

Сприймання та обговорення окремих із запропонованих творів поглибилось в результаті використання методики, спрямованої на емоційно-ціннісну складову особистісного художнього розвитку. Були передбачені наступні методи реалізації інтегративного підходу: “образні паралелі”, “емоційна рефлексія”, “вербальна інтерпретація" “емоційне налаштування”. Останній, зокрема передбачав стимулювання зацікавленості аудиторії темою.

Пам'ятаючи про важливість практичних форм роботи у шкільній мистецькій освіті, ми застосовували метод “мистецький поліглот”, що передбачав різномистецький переклад обрядовопісенної образності. Так, студентами створювались графічні “логотипи-символи”, елементарні рухи (“плетіння вінка”, “вітання сонця”, “уклін землі”, “топтання рясту” та ін.), вокальні вправи на матеріалі обрядових зразків 


\section{МЕТОДИЧНІ АСПЕКТИ РЕАЛІЗАЦЇ ІНТЕГРАТИВНОГОПДХОДУ У ПРОЦЕСІ ВИКЛАДАННЯ КУРСУ “ІСТОРІЯ МУЗИКИ” ДЛЯ МАЙБУТНІХ УЧИТЕЛІВ МИСТЕЦТВА}

(наприклад, західноукраїнських риндзівок, “гойкань”, гагілок), звукопластичий, вербальний, поетичний, фонопедичний типи супроводу до окремих творів та ін. Метод “вчительської майстерні”, спонукав до розв'язання запропонованих проблемних завдань (“Обрядовий фольклор запрошує до музикування”, "Пісенно-обрядові вправи для голосу учня”, “Обрядовий фольклор навчає музичній грамоті” та ін.), що відображають специфіку роботи вчителя мистецтва.

Таким чином, орієнтуючись на різнорівневу підготовку здобувачів вищої освіти, впливаючи на їх художній розвиток, ми використовуємо внутрішньопредметну, міжпредметну (“Методика музичної освіти”, “Історія мистецтв”, "Психологія" та ін.), загальнопредметну інтеграцію. Методика інтегрованого впливу, спрямовуючись на окремі структурні складові особистісного художнього розвитку, покликана сприяти цілісному фаховому розвитку майбутнього вчителя, здатного до самостійної інноваційної художньо-освітньої діяльності інтегративного змісту.

\section{ЛIТЕРАТУРА}

1. Нова українська школа. URL: https://mon.gov.ua/ $\underline{\text { ua/tag/nova-ukrainska-shkola }}$

2. Великий тлумачний словник сучасної української мови / Уклад. і голов. ред. В.Т. Бусел. Київ, Ірпінь: Перун, 2007.1736 c.

3. Данильян О.Г., Данильян О.Г. Глобалізація культури: протиріччя та тенденції розвитку. Вісник Національного університету "Юридична академія Украӥни імені Ярослава Мудрого”. 2017. №2 (33). C. 29-41.

4. Карпенчук С.Г. Філософія освіти (загальна теорія педагогіки): монографія. Київ: Видавничий дім “Слово”, $2013.688 \mathrm{c}$

5. Максимова В.Н. Межпредметные связи в учебновоспитательном процессе современной школы: учеб. пособие по спецкурсу для студентов пед. ин-тов. Москва: Просвещение, 1987.160 с.

6. Мариновська О. Інтегральна технологія навчання: від теорії до практики. Початкова освіта. 2011. № 32 (608). С. 3-5.

7. Масол Л.М. Методика навчання мистецтва у початковій школі: посібник для вчителів / Л.М. Масол, О.В. Гайдамака, Е.В. Бєлкіна, О.В. Калініченко, І.В. Руденко. Харків: Веста: Видавництво “Ранок”, 2006 $256 \mathrm{c}$.

8. Светловская Н.Н. Об интеграции как методическом явлении и ее возможностях в начальном обучении Начальная школа. 1990. № 5. С. 57-60.
9. Терентьева Н.А. Художественно-творческое развитие младших школьников на уроках музыки в процессе целостного восприятия различных видов искусства. Москва: Просвещение, 1990. 184 с.

\section{REFERENCES}

1. Nova ukrainska shkola [New Ukrainian school]. Available at: https://mon.gov.ua/ua/tag/nova-ukrainskashkola. [in Ukrainian].

2. Busel, T. (2007). Velykyi tlumachnyi slovnyk suchasnoi ukrainskoi movy [A great explanatory dictionary of modern Ukrainian]. Kyiv, Irpin: Perun Publ. 1736 p. [in Ukrainian].

3. Danylian, O.H. \& Dzoban, O.P. (2017). Hlobalizatsiia kultury: protyrichchia ta tendentsii rozvytku [Globalization of culture: contradictions and trends]. Bulletin of the National Yaroslav Mudriy Juridical Academy of Ukraine, No. 2(33), pp. 29-41. [in Ukrainian].

4. Karpenchuk, S.H. (2013). Filosofiia osvity (zahalna teoriia pedahohiky). [Education Philosophy (General Theory of Pedagogy)]. Kyiv: Slovo Publ., 688 p. [in Ukrainian].

5. Maksimova, V.M. (1987). Mezhpredmetnyie svyaziv uchebno-vospitatelnom protsesse sovremennoy shkolyi: Ucheb. posobie po spetskursu dlya studentov ped. in-tov [Intersubject communications in the educational process of a modern school: Special course textbook for students of pedagogical institutes]. Moskva: Prosveschenie Publ., 160 p. [in Russian].

6. Marynovska, O.Y. (2009). Formuvannia hotovnosti vchyteliv do proektno-vprovadzhuvalnoi diialnosti: teoriia i praktyka [Formation of teachers' readiness for project-implementation activities: theory and practice]. Ivano-Frankivsk: Symfoniia-forte Publ.; Poltava: Dovkillia Publ., 500 p. [in Ukrainian].

7. Masol, L.M., Haidamaka, O.V., Bielkina, E.V., Kalinichenko, O.V. \& Rudenko, I.V. (2006). Metodyka navchannia mystetstva u pochatkovii shkoli: Posibnyk dlia vchyteliv [Elementary school art teaching technique: A guide to teachers]. Kharkiv: Vesta: "Ranok" Publ., 256 p. [in Ukrainian].

8. Svetlovskaya, N.N. (1990). Ob integratsii kak metodicheskom yavlenii $i$ ee vozmozhnostyah $v$ nachalnom obuchenii [About integration as a methodological phenomenon and its capabilities in primary education]. Elementary School, No. 5, pp. 57-60. [in Russian].

9. Terenteva, N.A. (1990). Hudozhestvennotvorcheskoe razvitie mladshih shkolnikov na urokah muzyiki $v$ protsesse tselostnogo vospriyatiya razlichnyih vidov iskusstva [Artistic and creative development of elementary school students at music lessons during the process of holistic perception of various art forms]. Moskva: Prosveschenie Publ., $184 \mathrm{p}$. [in Russian].

Стаття надійшла до редакції 02.06.2020

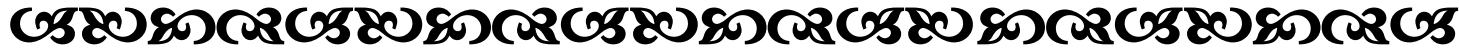

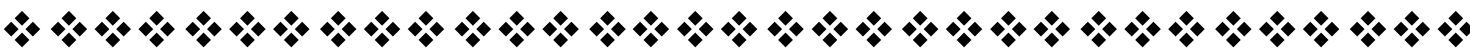

